
Susana Zapke, Stefan Schmidl (Hg.)

Partituren der Städte

Urbanstudies | UP Urbane Polyphonie 
Susana Zapke, Stefan Schmidl (Hg.)

\section{Partituren der Städte}

Urbanes Bewusstsein und muslkallscher Ausdruck 
Gefördert durch die Konservatorium Wien Privatuniversität der Stadt.

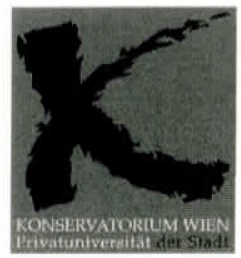

\section{Bibliografische Information der Deutschen Nationalbibliothek}

Die Deutsche Nationalbibliothek verzeichnet diese Publikation in der Deutschen Nationalbibliografie; detaillierte bibliografische Daten sind im Internet über http://dnb.d-nb.de abrufbar.

\section{(C) 2015 transcript Verlag, Bielefeld}

Die Verwertung der Texte und Bilder ist ohne Zustimmung des Verlages urheberrechtswidrig und strafbar. Das gilt auch für Vervielfältigungen, Übersetzungen, Mikroverfilmungen und für die Verarbeitung mit elektronischen Systemen.

Umschlaggestaltung: Kordula Röckenhaus, Bielefeld Umschlagabbildung: Alfred Kubin »Stadt Perle«, I9०9,

Eberhard Spangenberg/Bildrecht, Wien, 2013

Druck: Majuskel Medienproduktion $\mathrm{GmbH}$, Wetzlar

Print-ISBN 978-3-8376-2577-6

PDF-ISBN 978-3-8394-2577-0

Gedruckt auf alterungsbeständigem Papier mit chlorfrei gebleichtem Zellstoff. Besuchen Sie uns im Internet: http://www.transcript-verlag.de

Bitte fordern Sie unser Gesamtverzeichnis und andere Broschüren an unter: info@transcript-verlag.de 


\section{Inhalt}

Vorwort und Dank

Susana Zapke, Stefan Schmidl I 7

\section{Einführung}

Susana Zapke, Stefan Schmidl I 9

Partituren des Südens. Ein Versuch über Musikalien des barocken Neapel

Guido Erdmann | 19

Aaron Coplands New York , Citys

Timothy D. Freeze 139

Creating New Representations of Yugoslav National Territory. Dragotin Gostuški's Symphonic Poem Beograd

Srđan Atanasovski 159

Venezia. Fünf musikalische Annäherungen

Erich Wolfgang Partsch 177

Istanbul. Die Stadt als Serail

Michael Hüttler 189

Prag am Cover. Überlegungen zur Wahrnehmung von Stadtbildern für den Musikmarkt

Richard Kurdiovsky | 101

"A montanha, o sol, o mar ". Rio de Janeiro und seine symphonischen Repräsentationen Stefan Schmidl |117

Die Stadt als Partitur. Eine Wiener Komposition Susana Zapke | 127

Autorinnen und Autoren | 141 


\title{
Creating New Representations of Yugoslav National Territory ${ }^{1}$
}

\author{
Dragotin Gostuški's Symphonic Poem Beograd
}

\author{
SRĐAN ATANASOVSKI
}

In the following I will discuss symphonic poem Beograd (»Belgrade «) composed by Serbian author Dragutin Gostuški in 1951, and afterwards used for a musical »documentary television film « in 1969, in the context of the processes of building new representations of the state territory of socialist Yugoslavia. I will firstly discuss the particular political and social issues of territorial transformation in the early socialist Yugoslavia, reflecting on the theoretical issues of nation-state territorial authority and space representations. I will then specifically point out how the new territorial narratives of partisan warfare and rebuilding and development featured in the most poignant and all-pervading musical genre of the time, the mass song. Analysing Gostuški's symphonic poem, I will show how the topoi established in the mass songs penetrated his symphonic idiom, positioning this work as a part and parcel of the representations of space in the socialist Yugoslavia. Finally, referring to the two versions of the script< for the documentary film from 1969, I will discuss how the cult of labour and the rising cult of enjoyment were portrayed as parallel to the narrative of partisan warfare and positioned as a part of lived experience of the new socialist urban utopia.

1 The paper was written as a part of the project Serbian Musical Identities within Local and Global Frameworks: Traditions, Changes, Challenges (no. 177004/2011-2014/) funded by the Ministry of Education and Science of Republic of Serbia. 


\section{Producing Socialist Yugoslavia}

Territoriality, defined as a drive to govern over spatial flows in a certain bordered space, "to affect, influence, or control resources and people, by controlling area $\ll,{ }^{2}$ has been recognized as one of the main features of nationalism and of a nation-state. ${ }^{3}$ Ultimately, nationalism as such, in order for the people of the nation to exercise their purported sovereignty, has to achieve political independence, thus striving to create a nation-state, an instrument of power which is supposed to regulate and oversee a specific territory awarded to the nation. ${ }^{4}$ The question of the homeland is thus crucial in the discourses of the nationalism, as it concerns delineating the space which, by supposedly primordial natural laws, rightfully >belongs s to a nation. Through the mechanisms of governing established by the nation-state homeland is transformed into national territory, the poetic space into the space of governing. However, in order for a nation-state to effectively regulate spatial practices in the certain geographical area, homeland must always be in the perpetual state of becoming, representations of space are needed which would portray the homeland as inherently linked to the people of the nation. Authority of the nation-state is thus exercised and reaffirmed through social practices in which the territory of the state is being experienced by the members of the nation as stheir $<$ homeland.

Although Yugoslavia was represented as a supranational entity in the socialist era, it can be argued that in the aftermath of the Second World War Yugoslavia's statehood was designed to supplement and ultimately supplant historical national identities of south Slavic people, which were mostly based on ethnicity and religion. ${ }^{5}$ Yugoslavian identity openly fostered by Communist Party of Yugoslavia (Komunistička partija Jugoslavije) contained all major features of a national identity - the narrative of common (Slavic) ethnic origin, the myth of common struggle and sacrifice as the moment of the creation of the nation (Second World War partisan uprising), as well as the figure of nation-father (Josip Broz Tito) - cloaked under the rhetorically ambiguous slogan »fraternity and

2 Robert David Sack, Human Territoriality. Its Theory and History, Cambridge 1986, p. 1 .

3 Jan Penrose, $n$ Nations, states and homelands: territory and territoriality in nationalist thought«, in: Nations and Nationalism 8 (2002), pp. 277-297.

4 George W. White, Nationalism and Territory: Constructing Group Identity in Southeastern Europe, Lanham 2000, p. 19.

5 Cf. Siniša Malešević, Ideology, Legitimacy and the New State: Yugoslavia, Serbia and Croatia, London 2002, pp. 143-145. 
unity (»bratstvo i jedinstvo«), or deemed as »patriotism $«{ }^{6}$ However, it is important to note that while »fraternity and unity « de facto functioned as an ideology of a nation-state, it was formulated on radically different grounds compared to Croatian or Serbian nationalism, namely, as a Marxist ideology which positions its »golden age « into a future which is yet to be reached, contrasting nineteenth-century national myths which bespoke of the "golden age « positioned in the distant past. ${ }^{7}$ This different footing of Yugoslav >nationalism< demanded different representations of Yugoslav territory, a veritable transmogrification of how the space was perceived, creating a space of the future instead a space of the past, utopia instead of nostalgia. I would argue that, in order to create and maintain the nation-state's spatial web of power, narratives of a nation not only have to describe or bespeak of the certain geographical area envisaged as homeland, but have to be themselves spatial, embedded in the space, providing a kind of cognitive filter ${ }^{8}$ which invites citizens to recognize the values of their nation in the features of the landscape which surrounds them. The concept of representations of space, or conceived space (»l'espace conçu«) was proposed by Henri Lefebvre, as a part of his dialectics of the space, where he envisions social production of space as dialectical process where three aspects of space, perceived space, conceived space and lived space, are being dynamically juxtaposed. Representations of space reflect the »order « of social relations, they embed the signs, codes, and knowledge pertaining to these relations, and thus »they intervene in and modify spatial textures which are informed by effective knowledge and ideology«. As Lefebvre points out, this intervention »occurs by way of construction « - in other words by way of architecture, conceived of not as the building of a particular structure, palace or monument, but rather as a project embedded in a spatial context and a texture which call for »representations that will not vanish into the symbolic or imaginary realms «. ${ }^{9}$ Dismissing the imagery, Lefebvre points out that in order for representations of space to function as a cognitive filter, or to affect the texture of space, they have to be brought on the level of mate-

6 Cf. Marie-Janine Calic, Geschichte Jugoslawiens im 20. Jahrhundert, München 2010, p. 204.

7 Anthony D. Smith, Myths and Memories of the Nation, Oxford and New York 1999 , pp. 65-66.

8 Cf. the concept of >political cognition « developed by John Protevi; John Protevi, Political Affect: Connecting the Social and the Somatic, Minneapolis and London 2009, pp. 51-56.

9 Henri Lefebvre, The Production of Space, trans. Donald Nicholson-Smith, Oxford 1991, p. 42. 
rial immanence. However, his notion of »architecture « deserves a broad reading, as a totality of material practices which intervene in space in order to embed codes of power. Narratives of Yugoslav spatriotism< were thus from their onset engaged in creating new representations of space which would impart the underpinnings of the new power order and which would transform citizen's affective engagement within the space.

In order to understand the territorial project of the socialist Yugoslavia it is important to have in mind that the Yugoslav Communist Party's partisan warfare during the Second World War was practically resurrecting a defunct territorial and state project. First Yugoslavia, initially founded as Kingdom of Serbs, Croats and Slovenes in 1919 and organized as a parliamentary monarchy (although at a time governed as king's dictatorship), was constructed in the aftermath of the First World War in one fell swoop satisfied the ambitions of Kingdom of Serbia and its political elite, headed by Karađorđević dynasty, for territorial expansion and unification of the Serbs under one statehood, and of other South Slavs previously living in Austro-Hungary, which allegedly strived to exit this notorious »dungeon of nations «. However, soon after the unification the different agendas of rival political elites came to the fore, endangering even the adoption of the constitution in $1921 .{ }^{10}$ After vigorous political disagreements, ultimately resulting in assassination amongst the deputies in the very House of Parliament in 1928, king Aleksandar Karađorđević imposed dictatorship in the following year, abandoned the historical borders which were until then preserved in the state administration, and tried to enforce the concept of »integral Yugoslavism «, a doctrine according to which all Yugoslav people belonged to one nation, deeming all the differences between Slovenes, Croats and Serbs as "tribal ${ }^{11}$ However, the protests in the early 1930s, the assassination of the king in Marseilles in 1934, and constant rivalries between Serbian and Croatian political elites in the restored parliament testified of an utter failure of the doctrine. Following the rise of Axis powers, the framework of Europe as laid out by the Versailles Treaty began to crumble, and in 1939 Serbian political elite was forced to concede allowing the formation of Croatian »banovina « as a separate autonomous administrative unit. The new borders of Croatian banovina which crisscrossed the imagined homeland Yugoslav marked a final dereliction of the pro-

10 Calic, Geschichte Jugoslawiens (op. cit. in n. 6), pp. 86-87.

11 For integral Yugoslavism see Jovo Bakić, Ideologije jugoslovenstva između srpskog $i$ hrvatskog nacionalizma 1918-1941: sociološko-istorijska studija [Ideologies of Yugoslavism between Serbian and Croatian nationalism 1918-1941: sociological and historical study], Zrenjanin 2004. 
ject of building a unified Yugoslav state. Following the occupation by the Axis powers in 1841, the territory of Yugoslavia, already fraught with unrest, was further partitioned between Axis countries: batches of land became parts of Germany, Italy, Bulgaria, Albania, and several puppet nation-states were created.

Already at its Third Party Conference in 1924 (held illegally in Belgrade, as the party had been banned since 1921) Communist Party of Yugoslavia put forward a completely different vision of Yugoslavia's statehood, where the three nations of Slovenes, Croats and Serbs would be recognized, and further recognition of Montenegrins, Macedonians and Bosnian Muslims as nations would be possible. ${ }^{12}$ Since then, the guiding principle of the Communist Party of Yugoslavia would have been not to oppose »tribal« nationalisms, but to incorporate and "overcode « them with new generative and unifying myths. The national issue, which was so pernicious for the former kingdom, was apparently to be solved by granting to the each of the recognized nations the rights for self-determination and particular national identity, and at the same time, it was to be put aside, as a matter that has purportedly been resolved..$^{13}$ The chief overcoding myth was the partisan warfare against the Axis occupation led by the Communist Party, a strong guerrilla uprising which is considered one of the most virulent and successful resistance in the occupied Europe, managing to hold vast liberated territories by 1943. Party not only worked on creating the myth on partisan not only as intrepid fighters, but also as morally irreproachable ${ }^{14}$ Partisan uprising was portrayed as an unmediated act of the "people«, and further interpreted as the source of legitimacy of the new social order, as the "people « concurrently opted for socialism. The second overcoding myth was the cult of labour, inextricably linked with the narrative of economic progress, industrial development and better life. Cult of labour was, again, interconnected with the narratives of partisan warfare: the shock workers (udarnici), heroes of labour, were seen as equivalent to the heroes of war, and labour actions were seen in comparison to actions in combat. Everyday labour was seen as a second-best opportunity - as the warfare had ended - for the »labouring people« to engage in building the common liber-

12 Aleksa Djilas, The Contested Country. Yugoslav Unity and Communist Revolution, 1919-1953, Cambridge, MA and London1991, p. 71-72.

13 Thus, as Moša Pijade, a high official of the Communist Party, stated, the Yugoslav nations have been granted the right of political self-determination, but they have exercised their right once for all by joining the Yugoslav federation during the war against Nazism. Calic, Geschichte Jugoslawiens (op. cit. in n. 6), pp. 180-181.

14 Ben Shepherd, Terror in the Balkans: German Armies and Partisan Warfare, Cambridge, 2012, p. 152. 
ated socialist society. Up to early 1960 s the party leadership could have indeed believed that these myths, subsumed under the slogan of »brotherhood and unity« will eventually surpass »tribal« national myths and build the supranational identity of Yugoslav people, which will be more intensely embedded in citizens' everyday experience. Building nationalism par excellence in everything but name, the official discourse often elided to refer to the "Yugoslav people«, abundantly employing phrases characterized by Michael Billig as a daily banal flagging of the nation, ${ }^{15}$ such as »our nation «/»our people $«(» n a s ̌ n a r o d \ll)$, »nations $«$ (»narodi $«)$, or even »labouring people« (»radni narod $«)$ - equated with proletariat or with workers and peasants, whereas representing Yugoslavia as a land where they had ultimately been empowered. ${ }^{16}$

\section{LABOUR ACTIONS AND MUSICAL IMAGERY OF YUGOSLAVIAN TERRITORY}

In order to recuperate territory of Yugoslavia, the socialist regime needed to build the representations of space which would be based on radically different grounds and which would embody the narratives of partisan warfare and the cult of labour ushering them into the everyday affective experience. I will delve in more detail on two instances of such embodiment - the labour actions and the life in a new socialist industrial city. Voluntary youth labour actions (»dobrovoljne omladinske radne akcije «) were a practice of employing young people as volunteering workforce on the projects of infrastructural development. The labour actions were particularly important in the close aftermath of the Second World War, in the period between 1946 and 1952 with the participation of more than a million citizen, most notably in projects such as building railways BrčkoBanovići (1946) and Šamac-Sarajevo (1947), as well as commencing the construction of the district Novi Beograd in Belgrade (1948-51). After 1958 largescale labour actions organized on the national level were again installed, the largest being connected to the building of the Highway of Brotherhood and Unity (Auto-put bratstva-jedinstva). Labour actions acted as a mechanism of direct inscription of partisan war narratives into the cult of labour. The labour action and the warfare had in certain period actually coincided, as the actions were organized already in midst of the war in order to provide logistic for the frontline. The very organization of the labour actions resembled the structuring of an army,

15 Michael Billig, Banal Nationalism, London 1995, pp. 93-127.

16 Malešević, Ideology, Legitimacy and the New State (op. cit, in n. 5), pp. 148-149. 
as the volunteers were, for example, organized in brigades. Finally, the cultural life in the volunteers' camps was imbued with the topic of partisans: the partisan songs were sung, historical lectures were held, and many stories narrated around traditional campfires, even by the very officials of the army and war heroes who would come to the site. ${ }^{17}$ Bringing together youth from all the parts of socialist Yugoslavia, imbuing them with the stories from the war and fostering the cult of physical labour as a means of taming and conquering the nature, labour actions functioned as an effective melting pot of the new socialist country and mechanism of building spatial representations of the new regime. Interestingly, slogans of the regime used during work were often written with stones or drawn with lime into the mountain slopes. ${ }^{18}$ The infrastructural and industrial development was not ideologically neutral, but inextricably linked to the proclaimed values of the new society, serving as its long-lasting symbols. The representation of space were at once erected, perused, and experienced, embedding itself in the everyday life not as an ideological discourse but as affective practice.

In the years following the Second World War mass songs were the most representative feature of the new socialist Yugoslav music. Played both on radio stations and sung through numerous amateur choirs, ${ }^{19}$ mass songs were immensely popular, as well as effective in embodying the virtues of the new regime. The most prominent were partisan songs, directly connected and usually composed in the warfare, which were considered as a novel kind of folk songs, having sprung out directly from the people in the battle and being widely accepted within partisans themselves. ${ }^{20}$ Singing mass songs was also one of the most

17 Rudi Supek, Omladina na putu bratstva. Psiho-sociologija radne akcije [The youth on the path of brotherhood. Psycho-sociology of labor actions], Beograd 1963, pp. 9 10 and p. 51.

18 Report of the comrade Rade Vlkov (1947), Archive of Yugoslavia, Belgrade, collection "Savez socijalisticke omladine Jugoslavije « [League of Socialist Youth of Yugoslavia], folder 129 .

19 In the years immediately after Second World War there was a veritable explosion in the number of small amateur choir societies, which were associated to cultural societies, companies, trade unions, etc. Srđan Atanasovski, »Nikola Hercigonja i proizvođenje jugoslovenske nacionalne teritorije « [Nikola Hercigonja and production of the Yugoslav national territory], in: Mirjana Veselinović-Hofman and Melita Milin (eds.), Nikola Hercigonja (1911-2000), Čovek, Delo, Vreme [Man, Oeuvre, Time], Beograd 2011, pp. 143-144.

20 Nikola Hercigonja, »O partizanskim narodnim pesmama«, in: Napisi o muzici, Beograd 1972, pp. 274-305. 
impactful cultural practices on the sites of labour actions. Songs and slogans were loudly chanted during the work itself, and particularly during the march from the camp to the working site. Importantly, many amateur choirs were organized in the camp, and usually every »brigade « had one, with the numbers singers going in average from 20 to 30 . In the first shift of the labour action ŠamacSarajevo there were 155 choirs in 139 brigades, ${ }^{21}$ while at the camps in building Novi Beograd there were up to 342 choirs. ${ }^{22}$ Beside partisan songs, these choirs were also interpreting »labour songs «, the topic towards which composers mostly turned to after the war ended, celebrating the industrial and infrastructural development and endorsing the cult of labour. These songs often blatantly linked the partisan warfare narrative with advocating labour, such as in lines by Ferdo Škrljac: »the thrall has shattered his shackles; he is now on the forefront of the building ${ }^{23}{ }^{23}$ Composers would usually make several versions of a song, ranging from the version for a full-scale symphonic orchestra and four-part choir, designed for official performances, to a simple version for voice and piano, guitar or accordion, which would be mass printed and widely distributed. I will point out to two specific musical topoi which appear in the labour mass songs and which allow the singers and listeners to experience these messages on the tactile, bodily level: the military/march topos and topos of »openness «. An array of labour songs was written in a form of a march, juxtaposing the verses which extoll labour with the musical layer related to military practices. These songs often had a practical purpose too, being used by the workers in their daily marches to the construction site. Musical features include narrow vocal gamut suitable for marching singers, punctuated rhythm, strong bass line, as well as instrumental accompaniment which accentuates the march-like topos. As an example one can cite the beginning of the song Pjesma mladih graditelja (»Young builders' song«), composed by Lovro Županović verses by Grigor Vitez (example 1).

21 Materials from the labour action Samac-Sarajevo, Archive of Yugoslavia (op. cit. in n. 18).

22 Slobodan Selinić, »Život na omladinskim radnim akcijama u Jugoslaviji 1946-1963« [Life on the youth labor actions in Yugoslavia 1946-1963], in: Archiv 8 (2007), p. 8.

$23 »[\ldots]$ lance skida rob. U izgradnji sad je prvi [... ]«. Skrljac's song Ječi pjesma! (The song resounds!) was put to music by Marko Pavicić and published in 1948 (Zagreb: Glas rada). 
Example 1. Lovro Županović, Pjesma mladih graditelja, m. 1-6

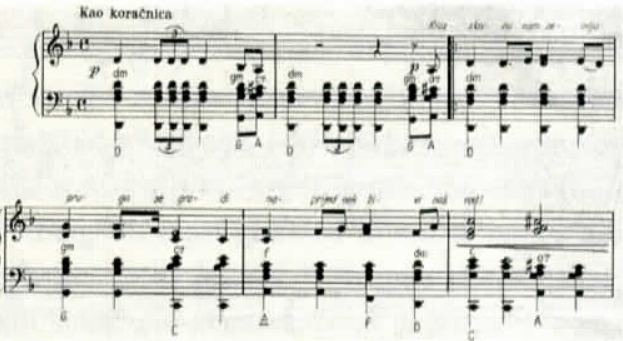

(tempo marking: »As a march«; lines: »Through our glorious land the railway is being build, ahead, long live our labour! $)^{24}$

Compared to the march topos, topos of openness often foregrounds dissimilar music characteristics, which invoke open spaces, the workers' facing the forces of sheer nature, and raise belief in the comprehensiveness of the industrial, infrastructural and urban development. The instrumental introduction often feature brass-section fanfares or fanfare-like melodic, the character of the song is triumphant and the vocal line is rampant (cf. Example 2, a song by Mihovil Logar with verses by Čedomir Minderović, which celebrates the concept of »zadruga« - cooperative, as a new model for organizing agriculture and associating individual producers).

Example 2. Mihovil Logar: Zadrugarska, m. 9-14

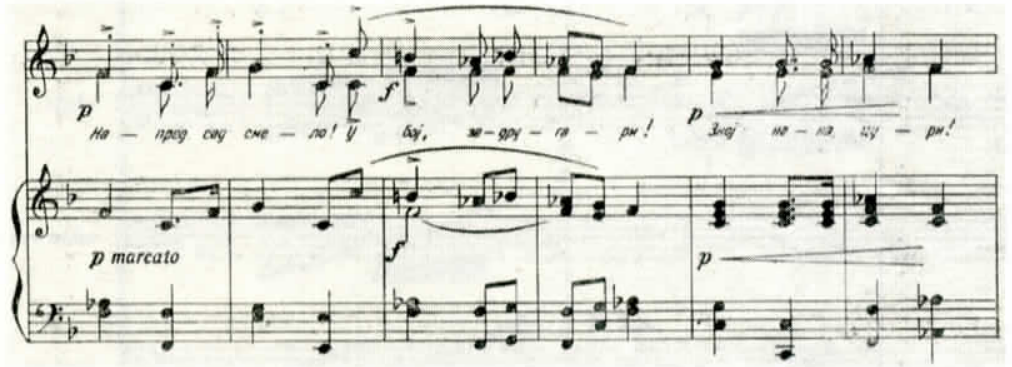

(tempo marking:»Enthusiastically«; lines: »Ahead now boldly! In combat, cooperatives! Let the sweat run! $\ll)^{25}$

24 Marcel Kasović (ed.), Drugarska se pjesma ori, Zagreb 1948, pp. 28-29.

25 Čedomir Minderović (text) and Mihovil Logar (music), Zadrugarska, Beograd 1949. 


\section{The Hopes of a Socialist City: BUILDING NOVI BEOGRAD}

The topos of openness is most clearly expressed in Nikola Hercigonja's song Pesma graditelja Novog Beograda (»Novi Beograd's builders' song«), written on Gvido Tartalja's verses and dating from 1949, which is directly linked with the voluntary youth labour action of building Novi Beograd, new district in the capital city. Hercigonja opens the full-orchestral version of the song with broad fanfare, which is then reflected in the instrument-like vocal line, while the parts of the string section are saturated with exhilarating upward passagework runs (see example 3$)^{26}$

Example 3a.Nikola Hercigonja, Pesma graditelja Novog Beograda, m. 1-4

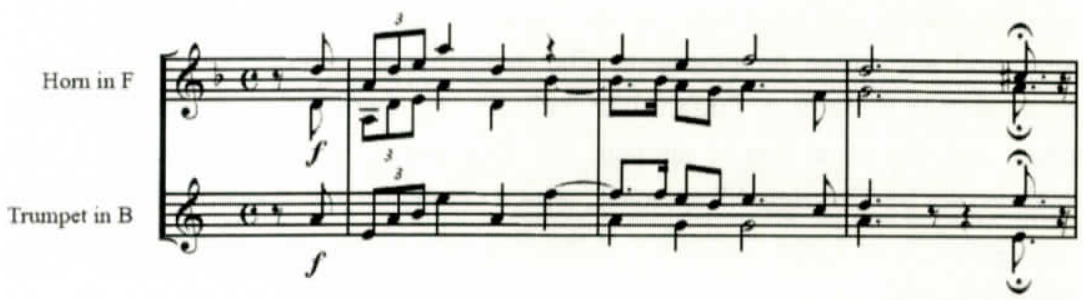

(horn and trumpet parts; tempo marking: Energico) ${ }^{27}$

26 Atanasovski, »Nikola Hercigonja« (op. cit. in n. 19), pp. 148-149.

27 Manuscript in Legacy collection of Nikola Hercigonja, RM 244, National Library of Serbia, Belgrade. 
Example 3b.Nikola Hercigonja, Pesma graditelja Novog Beograda, m. 5-12
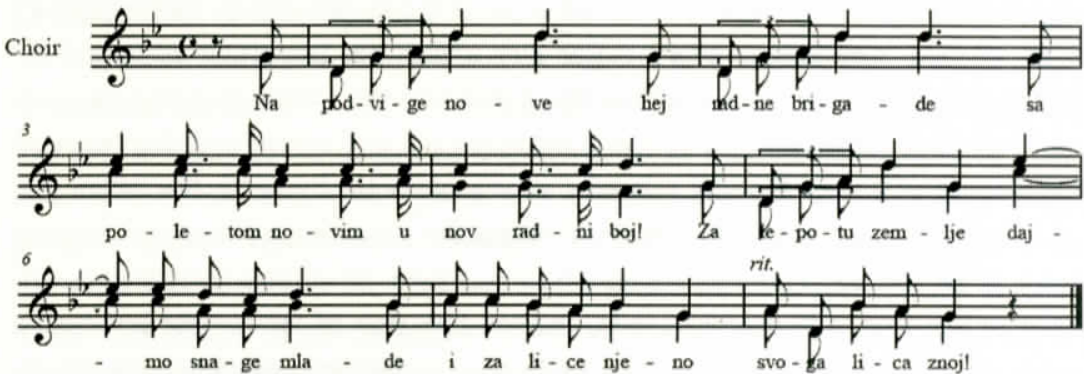

(vocal part; lines: „To new feats, hollo, labour brigades, with the new verve into the new work combat! For the beauty of the land let us give the young strength, for its visage - the sweat from ours!

Example 3c.Nikola Hercigonja, Pesma graditelja Novog Beograda, m. 15-16

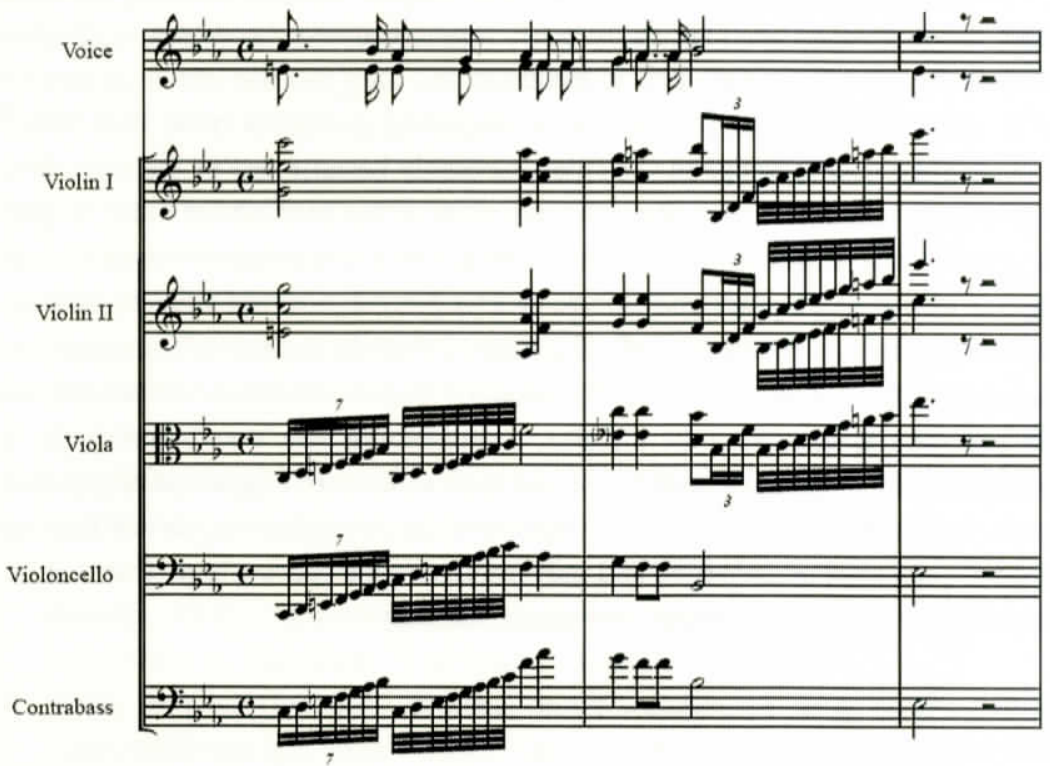

(vocal and string parts)

The project of constructing Novi Beograd, which commenced in 1948, was the most prominent in the array of projects of urban development, which were inex- 
tricably linked to industrialisation efforts. Industrialisation was associated with significant migrations from rural to urban areas, as more workers in the industry were needed, and almost every major city underwent important structural rebuilding in the first decade after the Second World War. Novi Beograd, projected in the area across the Sava River connecting the city centre with the old Austro-Hungarian city of Zemun, carried a strong symbolic charge as the future seat of the federation, where monumental buildings representing the new regime were to be erected. This vast barren space had been unsuitable for urban development because of its marshy lands, and the first part of the project involved a veritable transmogrification of the landscape, employing volunteers in procedures such as land drainage. During the project's development, the question of housing and everyday life was becoming more and more apposite, in an effort to create a living image of an egalitarian society. ${ }^{28}$

Urban centres were at the same time the most important representations of the socialist society which was to be built in Yugoslavia and true hubs of the rapid and successful (if not sustainable) processes of industrialisation. As testimonies of an »economic miracle « and urban revolution, already between 1947 and 1949 the number of workers in branches such as industry and mining quadrupled, and up to 1953 cities such as Belgrade and Sarajevo had grown in size for $18 \%$, while some industrial cities had a staggering growth of more than $50 \%{ }^{29}$ The need for new lodgings in the cities inevitably became one of the main driving forces of urban development. The members of the new labour force, migrating from the rural areas into the cities, were genuine conscripts of the new ideology, as their everyday life and culture of living revolutionized with the new social circumstances. Narratives of rebuilding, industrialization, urbanization and planned progress intertwined with the myth of Yugoslav >nation< embedded into the everyday existence of the citizens, as something they could experience in their practices of labour, inhabitation, as well as leisure. Not surprisingly, Belgrade, and especially Novi Beograd, was the ultimate migration hub and flagship of these processes urbanization and industrialization, a space where sheer habitation collided with new socialist state monumentality.

28 Ivan Kucina and Milica Topalović, »From Planned to Unplanned City: New Belgrade's Transformations«, in: Maroje Mrduljaš and Vladimir Kulić (eds.), Unfinished Modernisations. Between Utopia and Pragmatism, Zagreb 2012, p. 157; cf. Ljiljana Blagojević, Novi Beograd: osporeni modernizam [Novi Beograd: challenged modernism], Beograd 2007.

29 Calic, Geschichte Jugoslawiens (op. cit. in n. 6), pp. 196-198. 


\section{From Symphonic Poem to Television Vignette: GOSTUŠKI'S BEOGRAD}

Symphonic poem Beograd by Dragutin Gostuški (1923-1998) ${ }^{30}$ was composed in 1951, in midst of the described impetuous urban transformation. One of composer's few orchestral works, poem was designed as a graduation piece in composition at the Belgrade Music Academy. ${ }^{31}$ Laid out in a clear-cut sonata form, the work was written at the very end of the period of an unprecedented stylistic uniformity across all generations of composers who were active in Yugoslavia, as all resorted towards rather conventional style vaguely associated with social realism. ${ }^{32}$ However, after the disagreements between Tito and Stalin and schism with the Soviet Union, artists in Yugoslavia were invited to experiment more freely with modernism. The same year the symphonic poem was composed, Gostuški travelled as one of the students of composition to Munich, to an international meeting of music students, which was the first post-war contact with Western Europe for composers of Gostuski's generation. ${ }^{33}$ Although early 50s were the period of artists' exploration of new liberties that were awarded to them, the control of the Communist Party over the art production was inces-

30 Composer, musicologist and art historian, Gostuški was born in Belgrade, where the also graduated history of art and composition, subsequently earning his $\mathrm{Ph} . \mathrm{D}$. at the Faculty of Philosophy. Most of Gostuski's compositions belong to his early period, from late $1940 \mathrm{~s}$ and early $50 \mathrm{~s}$, with notable exception of choral works from early $60 \mathrm{~s}$. Gostuski dedicated most of his carrier to scholarly work, as a researcher in the Institute of Musicology SASA, primarily writing in the fields of music theory and comparative aesthetics, while remaining active as an art and music critic. For detailed biographical data and Gostuški's bibliography, see Katarina Tomašević, »Dragutin Gostuški, Ph.D., Musicologist and Composer (Belgrade, 3.1.1923 - Belgrade, 21.9.1998)«, in: Musicology 10 (2010), pp. 211-222.

31 Beside Beograd, Gostuski's orchestral oeuvre encompasses pieces Scherzo (1949), Valse (1950) and Igra utroje (»Play for three«, 1952 or 1953), ballet Remi (»Draw«, 1955) and Concerto accelerato for violin (1961).

32 Ivana Medić, »The Ideology of Moderated Modernism in Serbian Music and Musicology«, in: Musicology 7 (2007), p. 284.

33 Melita Milin, Tradicionalno $i$ novo u srpskoj muzici posle Drugog svetskog rata (1945-1965) [The traditional and the new in Serbian music after the Second World War], Beograd: Muzikološki institut SANU 1998, p. 53. 
sant. ${ }^{34}$ The resulting stylistic orientation is often dubbed "moderated modernism«, a »non-challenging form of modernism « which lacks critical distance towards the tradition that precedes it and uses stylistic emblems of avant-garde in an ostensive manner. ${ }^{35}$ Gostuški's poem Beograd can be recognized as such crossover from socialist realism towards moderated modernism. Beside references to the topoi present in the mass songs which I will discuss, Gostuški employs cluster-like harmonies, as well as collaged appearance of form which also reveals a strong influence of western-style film music.

Gostuški's symphonic poem Beograd features both topoi of mass songs connected with labour thematic in a very prominent manner. The topos of openness is present in the very beginning of the poem, in the introduction featuring a striking solo trumpet signal accompanied by tremolo in timpani and ending with passagework upward runs in strings and flute (m. 1-17, see example 4). The trumpet signal continues to appear in the piece, while its motivic material is worked through mainly in the woodwind section. Motif of trumpet fanfares is introduced afterwards, in the first subject, and remains structurally important throughout the poem. The integral introduction material is again presented in recapitulation, this time in a pastoral setting, including harp and woodwinds in the instrumentation (m. 259 et seq.). Military topos is most arresting in the development section, where an outright Alla marcia periodically structured episode is presented, with galvanizing orchestral effects, including snare drum, woodwind and brass section, etc. (m. 217-244, see Example 5). Unmistakable reference to mass song genre is also included in this episode, with a chant-like material clearly displayed in strings and violas playing unison, followed by cantabile fanfare of three trumpets (m. 225 et seq.). Gostuški's music portrait of the capital city of Yugoslavia thus heavily relies on the already established musical vocabulary of mass songs, promoting ideals of new social urbanism and development.

34 Ješa Denegri, Pedesete: teme srpske umetnosti (1950-1960) [The fifties: themes in Serbian art], Novi Sad 1993, p. 7.

35 Medić, »The Ideology of Moderated Modernism« (op. cit. in n. 32), pp. 279-282. 
Example 4.Dragutin Gostuški, Symphonic poem Beograd, m. 1-9

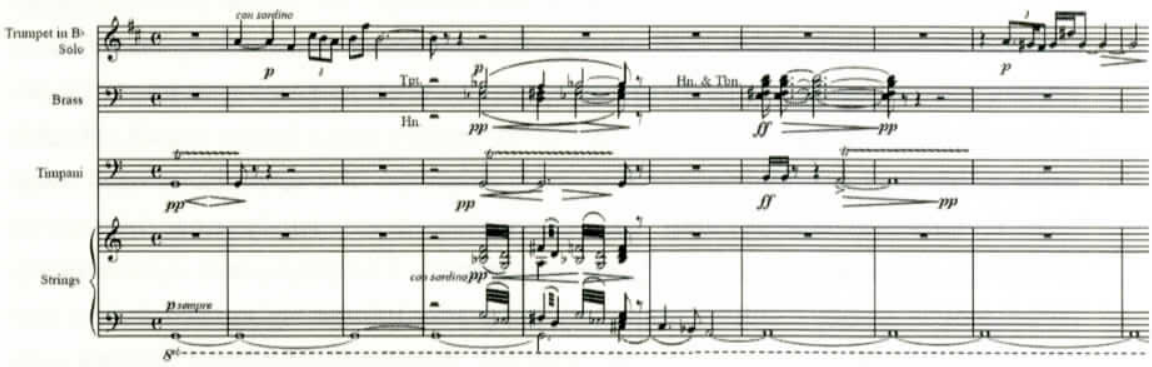

(solo trumpet, brass, timpani and strings parts) ${ }^{36}$

Example 5.Dragutin Gostuški, Symphonic poem Beograd, m. 217-222

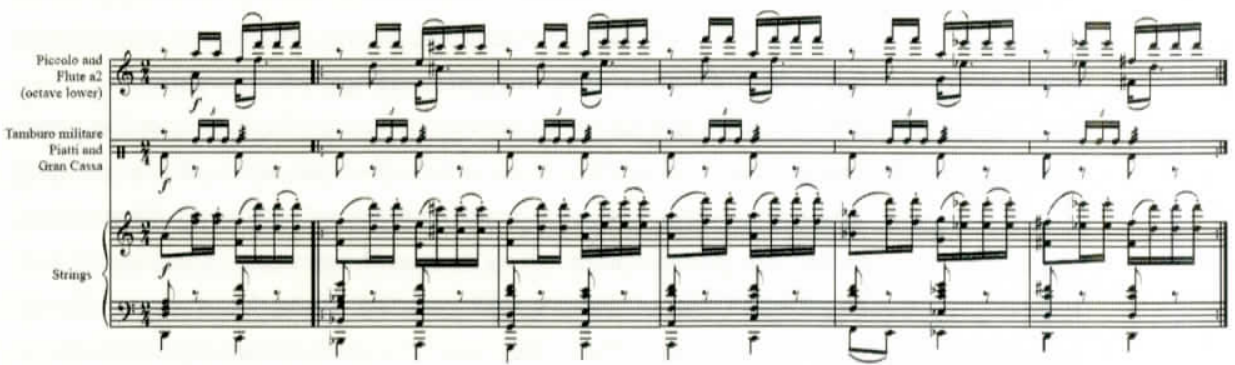

(piccolo, flute, percussions and strings parts)

Having in mind the likeness of Gostuški's score to the western film music of the day, it is not surprising that composer desired to use his poem as music for a >documentary film< about Belgrade. Filmed for the celebration of twenty-fiveyears' anniversary of Belgrade's liberation, the film featured no spoken text but instead relied solely on the interaction between the music and the moving images, being more of a stelevision vignette $<$ than a proper documentary film. Eschewing the words, Gostuški tried to distance the film from blatant propaganda. There are two extant versions of a >script $<$ written by Gostuski in preparation of the making of the film, which are precious and revelatory material both for understating the symphonic poem itself and the desired effect which the film

36 Examples are based on manuscript in the library of Belgrade Philharmonic Orchestra. 
should have produced. ${ }^{37}$ These scripts, in fact, consist of a list of more or less detailed descriptions of scenes which are to be accompanied by the poem, explicating the imagined narrative. Introducing the project of film-making in the first, shorter version of the script, Gostuski speaks of his poem as a »rounded composition for large orchestra, written in the so called sonata form « which, »beside pure aesthetical«, »contains certain programmatic character in several wide shots«. Gostuški claims that, »by alternating dramatic, lyric and dynamic moods", he had had »a vision of concrete images of Belgrade and, in its entirety, its historical destiny « while composing the piece. Interestingly, the musical features which were pointed out as intertextually linked with the topoi of mass song feature prominently in Gostuški script: they are being given important roles in the narrative and they are linked with specific camera effects. The »signal of a (military) trumpet« provokes rising and movement of the camera accompanied by landscape shots, »fanfares « accompany monumental visions and wider aerial views of Belgrade, while the »triumphant march « brings images of war victory emblems presented in vertiginous rhythmical alternating of single shots.

The utopia of new social urbanism is, however, not laid out as a static panegyric, but is represented as a dynamic state reached at pinnacle of historic and social struggle. Historical time features prominently in Gostuški's film script, where he refers to his symphonic poem as to a »heroic epopee «. The idea of historical progress leading to the socialist society as the pinnacle of social development was deeply rooted in the official Marxist interpretations and in the rhetoric of the Communist Party. The official historical narrative strived to subsume the "glorious moments « of belligerent resistance found in the histories of individual Yugoslav nations under the common legacy and to construe them through the lens of class struggle. ${ }^{38}$ Adapting the historical narrative to the structure of the poem, Gostuški envisioned two large musical and dramatic gradations, the first one leading to the "triumphant march « and the end of the development section, and the second one spanning the recapitulation. The first gradation sets of at the beginning of the development section, after the exposition had featured landscape images and scenes of Ottoman legacy. It opens with an image of a storm, summarizes the wars against the Ottoman Empire and the First World War, reaching the images of partisan warfare, which are then apotheosized in the

37 The scripts, entitled »Beograd. Scenario « and »Beograd. Scenario za jedan dokumentarni film u boji na muziku simfonijske poeme >Beograd D. Gostuškog «, are kept in the Dragutin Gostuški's legacy in the Archive of the Institute of Musicology SASA in Belgrade. I have not been able to locate a copy of the film itself. 
march and the serene ending of the development. The second gradation is capsuled and ensues after the pastoral and idyllic images of landscapes, representational buildings and residential neighbourhoods featured in the recapitulation of the first and beginning of the second subject group. This time gradation starts with the image of "pre-war dessert at the terrain of today's Novi Beograd « and again features the topos of openness, such as trumpet fanfares, upward tremolo motion in strings and timpani's tremolo (m. 306-312). This terrain is then showed as it »flows over into construction sites, and then into monumental structures « and the apotheosis is reached with images of Novi Beograd residential skyscrapers and official buildings. Gostuški openly states that »special attention, in the key points of the film, will be paid to the current layout of Belgrade, illustrating the enormous efforts that have been made in the post-war period of construction works«. Indeed, Novi Beograd was awarded with a matchless position, with its panorama closing the film accompanied by the sounds of final fanfares a hallmark that even superimposes the widest areal shot. However, the poem and the television vignette do more than this. In presenting the two musical gradations as historical processes, they vividly portray the laborious efforts of the $\mathrm{Yu}$ goslav working class and the projects of urban restructuring as analogous to the partisan warfare. The labour and the realization of the new urban utopia are seen in parallel to partisan combats and as their continuation, as an opportunity to relive the experience of the freedom fighters on the level of everyday life.

Portraying idyllic images of dwelling in the new urban utopia Gostuški film is quite representative of $60 \mathrm{~s}$, when the cult of enjoyment gradually came to supplant and replace the cult of labour. Unlike most of the countries of the Eastern bloc, Yugoslavia was engulfed with the global discovery of the free-time, leisure and everyday enjoyment, which was no more reserved only for the handful of wealthiest citizens. The question of appropriate and comfortable dwelling was one of the most important issues at the intersection of this new cult and the deluges of city's newcomers lured to the urban areas with the rise of industry and service sector. For many city newcomers the issue of pleasant and homelike lodging was the crucial and ultimate test of the new regime, which was promising its citizens the comforts of everyday life befitting of a successful industrial society. The questions in the official field of urbanism also turned from monumental projects towards housing, while Novi Beograd was to become the most extensive and fittest residential district. ${ }^{39}$ In his script Gostuški inextricably links

39 Cf. Tanja Damljanović and Jelica Jovanović, »Belgrade Residential Architecture 1950-1970: A Privileged Dwelling for a Privileged Society«, in: Mrduljaš and Kulić, Unfinished Modernisations (op. cit. in n. 28), pp. 294-311 
the monumental emblems of the communist-party rule with the images of everyday life. The »monumental buildings «, such as the seat of the Central Committee and the Palace of the Federation, are accompanied with residential quarters both in Novi Beograd and in the older parts of the city. This way the triumphant music of the poem is associated not only with the state monuments but also accompanies the everyday, the true battlefield of the revolution and socialism.

Following Lefebvre's clues, one may interpret utopian image as "something lived «, distinct and more effective of ideology itself, which is conceptualized as an established truth; utopia »appears as an immediate possibility«, as »the image of what is possible transferred into reality $\ll .{ }^{40}$ Broadcasted on state television in autumn 1969, Gostuški symphonic poem and the television vignette undoubtedly stand as representations of space of the socialist Yugoslavia. Intervening through a powerful public rostrum such as television, Gostuški's artwork offered not only an image of the capital city in a form of »heroic epopee «, but a matrix through which the citizens of this new society could interpret their everyday life and construe their environment. In this key, the quotidian practices of dwelling and labour could be lived as a part of the socialist urban utopia, the immanent reality of the promised society.

40 Henri Lefebvre, Introduction to Modernity: Twelve Preludes, September 1959 - May 1961, trans. John Moore, London 1995, p. 91. 
Das Design und die Entzifferung des Urbanen vollziehen sich zugleich auf multiplen Ebenen sozialer Konfigurationen und künstlerischer Wahrnehmung. Stadt ist somit way of life, Projektionsfläche, Image und imaginärer Lebensraum, der seit dem 19. und 20. Jahrhundert eines der zentralen programmatischen Motive in Literatur, Malerel, Film und Musik bildet.

Im Zentrum dieses Bandes stehen ausdrücklich musikalische Deutungen. Die Beiträge geben Einblick in die Vielfältigkeit künstlerischer Stadterfindungen und untersuchen anhand unterschiedlicher Metropolen-Porträts differenzierte Reaktionen auf das Städtische, Optiken und Ausdrucksformen sowie die Vergangenheit und Gegenwart urbaner Imaginationen. 